\title{
COMPARISONS OF METHODS TO STUDY THE PROCESSING OF Alnus glutinosa AND Eucalyptus globulus LEAVES IN A FORESTED HEADWATER STREAM.
}

\author{
E. S. López, N. Felpeto \& 1.Pardo. \\ Departamento de Ecología y Biología Animal, Facultad de Ciencias, 36200 Vigo, Spain
}

Keywords: Litter breakdown, methodological comparisons, alder, eucalyptus.

\section{SUMMARY}

Different methods for determining leaf breakdown rates and invertebrate colonisation were compared in the Mera, a small upland stream located in NW Spain, in autumn 1996. The experiments were designed to assess the effects of incubation technique, incubation site, leaf age, and leaf species. Incubation techniques compared for abscised alder leaves were packs, brick packs, and bags. Decay was fastest in packs, followed by bags and brick packs. Invertebrate richness, density and collector numbers were higher in bags than in packs and brick packs; shredders were most abundant in packs. Creen eucalyptus leaves incubated in packs and bags yielded similar results: faster breakdown in packs (ANCOVA, $\mathrm{F}=8.92, \mathrm{p}=0.005$ ), but higher invertebrate density and richness (ANOVA, $\mathrm{F}=4.69, \mathrm{p}=0.037$ ) in bags. Packs of abscised alder had very similar decay rates in pools and riffles, whereas invertebrate densities, richness and collector densities were higher in pools, and shredders were best represented in riffles (ANOVA, $F=4.78, p=0.036$ ). Leaf quality was compared studying the effect on decay rates of leaf age and leaf species. Green alder leaves were processed faster than abscised ones (ANCOVA, F $=7.44, p=0.009$ ), and showed higher invertebrate densities (particularly Brillia modesta, the dominant shredder), but more shredders were found on abscised alder leaves. Eucalyptus and green alder leaves showed nearly identical decay rates, although alder was colonised by more taxa (ANOVA, $\mathrm{F}=11.18, \mathrm{p}=0.002$ ) and individuals (ANOVA, $\mathrm{F}=6.73, \mathrm{p}=0.014$ ), and was preferred by $B$. modesta (ANOVA, $\mathrm{F}=12.77, \mathrm{p}=0.001$ ).

Our results show differences in the experimental designs examined. The choice of the best method should be based on close reproduction of natural conditions in similar streams, on reliability, simplicity and economy. Abscised leaves enter the streams and accumulate as loose packs, in both riffles and pools, according to flow patterns. Packs were processed at similar rates in riffles and pools, although riffles are dominant habitats in these headwater streams, and thus, easy to find and sample. Creen leaf material showed differences in leaching, and is not useful as homogeneous starting material. Differences between the native versus the introduced leaf species, mainly consisted in differences in invertebrate colonisation patterns, which have strong implications for nutrient cycling through the benthic community. Biological indicators can be useful to search for optimal methods to be used in litter processing studies.

\section{INTRODUCTION}

The comparison of results from litter processing studies is still problematic. In addition to the insoluble problem of accounting for all factors affecting breakdown rates, major difficulties are created by the use of different techniques. Differences in leaf breakdown rates have been attributed to incubation techniques (BENFIELD et al., 1979; BLACKBURN \& PETR, 1979; IMBERT \& POZO, 1989), leaf pack location in the stream (BENFIELD et al., 1979; CUMMINS et al., 1980), differences in the quality of green and abscised leaf material (CAMPBELL et al., 1992), type of leaf pre-treatment (BOULTON \& BOON, 1991) and size of experimental leaf packs

Limnetica, 13(2): 13-18(1997)

J. Pozo \& A. Elosegi (eds),

Proceedings of the European Meeting on Litter Breakdown in Rivers and Streams

c) Asociación Española de Limnología, Madrid, Spain.
(REICE, 1974; BENFIELD et al., 1979).

This study was designed to examine the effect of some of such variations on litter breakdown rate and invertebrate colonisation in a typical Galician headwater stream, which flows through a granitic, forested catchment dominated by alder (Alnus glutinosa (L.) Gaertner). This native species is frequently replaced by eucalyptus (Eucalyptus globulus, Labill) in the area, and litter processing studies in nearby areas in N Spain (POZO, 1993; BASACUREN \& POZO, 1994) and N Portugal (CORTES et al., 1994; ABELHO \& GRAÇA, 1996) have reported differences between both leaf species and have suggested consistent implications for stream communities. Several methods were compared to analyse the effect of incubation 
technique, incubation site, leaf age and leaf species. The main purpose of this study was to identify the inost appropriate metIiod for future studies. The criteria on which the assessment was based were degree of simulation of natural conditions. reliability, simplicity. and required effort.

\section{STUDY SITE}

The study was conducted in the headwaters oí' the Mera, a small tributary of the River Miño, in the central part of Galicia, NW Spain (fig. 1). The climate is continental oceanic, with a mean annual ternperature oí' 10-13 "C and a inean annual rainfall of $1.000 \mathrm{~mm}$. Rain falls mainly in autumn and winter; summers are characterised by lower rainfall.

The study was conducted in a second order (sensu STRAHLER, 1964) reach, $50 \mathrm{~m}$ long, $3 \mathrm{~m}$ wide on average, at an altitude of $520 \mathrm{ni}$ a.s.l. The riparian corridor is dominated by alder, and is bordered by a mixed forest (chestnut, oak and birch) on the right. and by meadows on the left bank. The reach has riffles 20 to $30 \mathrm{~cm}$ deep, alternating with pools 50 to $60 \mathrm{~cm}$ deep; the substrate is composed of cobbles and pebbles lying over gravel and coarse sand. The stream water is slightly acid (mean $\mathrm{pH}$ during the study of 6.4) with low concentrations of dissolved solids (specific conductivity of $43.9 \mu \mathrm{S} \mathrm{cm}^{-1}$ ). In autumn 1996. water teinperature ranged from 4 to $12^{\circ} \mathrm{C}$. with a mean value of $8{ }^{\circ} \mathrm{C}$.

\section{MATERIALAND METHODS}

A total of four experiments were performed. To examine the effect of incubation technique, we studied the breakdown of abscised alder leavec assembled into different types of experiinental units which are referred to as packs, brick packs, and bags. Packs consisted of leaves tied together with nylon mono-

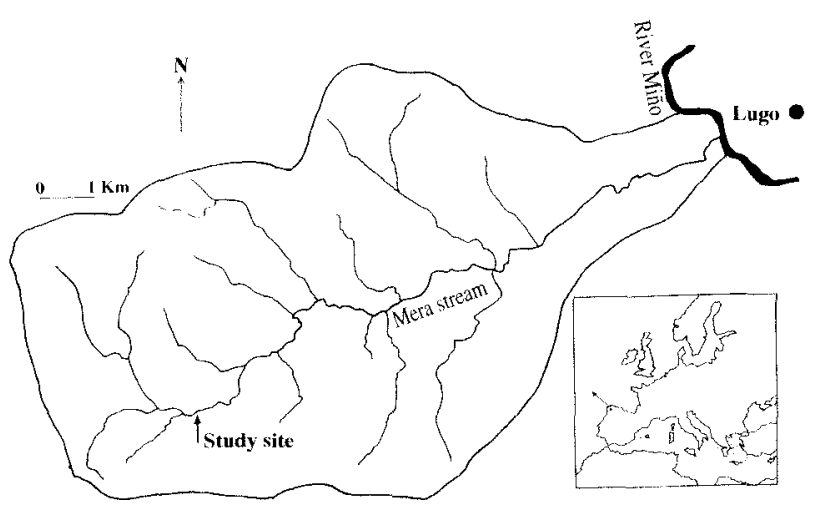

Figure 1 The Mera catchment and study site filament line and attached by means of a 20-cin piece of wire to a brick, which in turn was tied to a tree. Brick packs consisted of leaves tightly tied on top of a brick, which was also fixed to a tree. Bags had a mesh size of $5 \mathrm{inm}$. For eucalyptuc the comparison was restricted to green leaf packs and bags. The effect of incubation site was evaluated by comparing packs of abscised alder leaves incubated in riffles versus pools. The effect of litter quality was studied by comparing packs of green versus abscised alder. and green alder versus green eucalyptus leaves, thus taking into account both leaf age and species as potential factors causing variability.

Green leaves were picked froin trees, and abscised leaves were collected daily with nets. Green and abscised leaves were oven dried at 50 " $\mathrm{C}$ and asseinbled into $5 \pm 0.1 \mathrm{~g}$ packc which were subsequently assigned to the different experimental units (i.e., packs, brick packs or bags) and placed in the study stream. The packs were sainpled on five occasions: the first time three days after placement in the stream, and subsequently in one- or two-week intervals. Four replicates per treatment were sampled at each time. To control for losses in leaf mass because of handling, all leaf packs were initially transported to the study site, placed in the stream, and the first cet of replicates immediately removed and processed in the same way as on subsequent sampling dates. In the laboratory, packs were washed, invertebrates sorted and preserved in $70 \%$ ethanol; the leaves were ovendried to constant weight ( $18 \mathrm{~h}, 80$ "C).

After adjustment for handling losses, the leaf mass remaining versus time (days) was fitted to an exponential model. Analysis of covariance (ANCOVA) was used to detect differences iii decay rates between treatments.

Data on species richness and densities of rnacroinvertcbrates were $\log (x+1)$ transformed, except for the relative densities of functional feeding groups, which were arc-sine square-root transformed. After data transformation, one-way analyses of variance were performed to detect significant differences between treatments. Subsequent pair-wise comparisons were performed with Tukey's test.

\section{RESULTS}

\section{Leaf breakdown}

Absciced alder leaves showed higher mass losses due to handling in packs than in brick packs and bags (table 1). A similar trend was apparent from the calculated decay rates, but differences were not statistically significant (ANCOVA, F = $1.91, p=0.157$ ). Slightly higher leaching was found in bags and brick packs than in packs. Mass losses due to handling and 
Table 1. Mean and standard error of percentage mass loss due to handling, and percentage of remaining mass per species and treatment on each sampling time.

\begin{tabular}{|c|c|c|c|c|c|c|c|c|c|c|c|c|}
\hline & \multirow{2}{*}{\multicolumn{2}{|c|}{$\begin{array}{c}\text { handling } \\
0 \text { days }\end{array}$}} & \multirow{2}{*}{\multicolumn{2}{|c|}{$\begin{array}{l}\text { leaching } \\
3 \text { days }\end{array}$}} & \multicolumn{8}{|c|}{ breakdown dynamics } \\
\hline & & & & & & & 21 & ays & 36 & & $51 \mathrm{da}$ & \\
\hline & mean & S.E. & mean & S.E. & mean & S.E. & mean & S.E. & mean & S.E. & mean & S.E. \\
\hline AP (alder, packs) & 11 & 1.0 & 88 & 5.0 & 81 & 5.0 & 68 & 5.0 & 45 & 4.0 & 12 & 2.0 \\
\hline $\mathrm{AB}$ (alder, bags) & 07 & 1.0 & 80 & 7.0 & 81 & 3.0 & 68 & 7.0 & 47 & 8.0 & 42 & 10.0 \\
\hline $\mathrm{ABr}$ (alder, bricks) & 08 & 1.0 & 83 & 6.0 & 78 & 3.0 & 67 & 4.0 & 57 & 6.0 & 47 & 9.0 \\
\hline AG (alder, green) & 07 & 0.0 & 74 & 4.0 & 69 & 8.0 & 54 & 5.0 & 26 & 3.0 & 12 & 2.0 \\
\hline API (alder, pools) & 11 & 1.0 & 77 & 6.0 & 79 & 1.0 & 65 & 2.0 & 54 & 6.0 & 17 & 6.0 \\
\hline EP (eucalyptus, packs) & 03 & 0.0 & 85 & 1.0 & 76 & 1.0 & 61 & 6.0 & 27 & 3.0 & 10 & 1.0 \\
\hline EB (eucalyptus, bags) & 04 & 1.0 & 87 & 2.0 & 77 & 1.0 & 71 & 2.0 & 57 & 3.0 & 33 & 11.0 \\
\hline
\end{tabular}

leaching were nearly identical in eucalyptus packs and bags (table 1), whereas breakdown rate was higher in packs than in bags (table 2).

Leaching of abscised alder packs was more pronounced in pools than in riffles (table 1), but overall breakdown was slightly, although not significantly, faster in riffles (table 2).

Abscised leaves were more affected by handling than green ones (mass losses of $11.0 \pm 1.0$ and $7.0 \pm 0.0$, respectively), but leaching was more important in green leaves (table 1). The breakdown rates of green leaves were significantly faster than those of abscised leaves although identical amounts of mass remained at the end of the experiment (table 2). Mass losses due to handling and leaching were greater for green alder than for green eucalyptus leaves (table 1), but the breakdown rates were similar (table 2).

\section{Macroinvertebrate colonisation}

A total of 52 taxa colonised the leaves, with the fauna being dominated by Diptera (16 taxa) and Trichoptera (15 taxa). Diptera accounted for $66.2 \%$ of the invertebrate density, followed by Plecoptera $(14.2 \%$ ). Collector-gatherers made up 40.4 $\%$ of the invertebrates, followed by shredders $(34.4 \%)$ and predators $(18.0 \%)$. The shredding chironomid, Brillia modesta Meigen, was the most abundant invertebrate in this study, with $23.7 \%$ of the total invertebrate numbers. Other Orthocladiinae were the dominant collectors, accounting for $18.3 \%$ of the total in vertebrate density.

For abscised alder leaves, bags showed the highest invertebrate richness and density. Absolute numbers and the proportion of shredders was highest in packs; $B$. modesta was nearly twice as abundant in packc as in brick packs and bags (table 3 ). A similar trend was observed for collectors in bags, with the Orthocladiinae being the group accounting for this effect. The colonisation of eucalyptus leaves in bags and packs showed trends similar to those found on alder (table 3). Only richness was significantly higher in bags (ANOVA, $\mathrm{F}=4.69, \mathrm{p}=0.037$ ). Collectors were more abundant than shredders on eucalyptus leaves, especially in bags (table 3 ).

In packs made from abscised alder leaves, invertebrate density and species richness were higher in pools than in riffles, and so were collector densities (table 3 ). In contrast, shredders reached a higher density in riffles (ANOVA, $\mathrm{F}=4.78, \mathrm{p}=$ 0.036).

Table 2. Breakdown rates $\left(\mathrm{k}, \mathrm{day}^{-1}\right)$, confidence intervals $(95 \%)$, and ANCOVA $(\mathrm{F}, \mathrm{p})$ for different comparisons.

\begin{tabular}{llllll}
\hline COMPARISONS & $-\mathrm{k}$ & $95 \% \mathrm{CI}$ & $\mathrm{F}$ & $\mathrm{P}$
\end{tabular}

1- Exposure technique:

Alder:

AP (packs)

$\mathrm{AB}$ (bags)

$\mathrm{ABr}$ (bricks)

Eucalypt:

EP (packs)

EB (bags)

$-\mathrm{k} \quad 95 \% \mathrm{CI}$

2- Incubation site for alder:

$\begin{array}{lll}\text { AP (riffles) } & 0.0329 & 0.0035 \\ \text { API (pools) } & 0.0383 & 0.0085\end{array}$

API (pools) $\quad 0.0383 \quad 0.0085$

3- Leaf age for alder:

$\begin{array}{lll}\text { AG (green) } & 0.0391 & 0.0027\end{array}$

AP (abscissed) $\quad 0.0329 \quad 0.0035$

4- Leaf species:

$\begin{array}{lll}\text { EP (eucalypt) } & 0.0449 & 0.0031\end{array}$

$\begin{array}{lll}\text { AG (alder) } & 0.0391 & 0.0027\end{array}$
$0.182 \quad 0.6762$

$7.437 \quad 0.0094$

$0.149 \quad 0.7089$

$1.908 \quad 0.1565$

$8.918 \quad 0.0046$

$0.0449 \quad 0.0031$

0.6762

0.149 . 0.7089


More taxa and higher densities were found on green than on abscised alder leaves. The relative abundances of shredders and collectors were similar on green leaves, but shredders dominated the macroinvertebrate assemblages on abscised leaves (table $3)$. Green leaves supported higher numberc of $B$. modesta and Orthocladiinae than abscised leaves.

Alder packs showed richer invertebrdte asseinblages (ANOVA, $F=11.18, p=0.002$ ) and higher densities than eucalyptus packs (ANOVA, $F=6.73, p=0.014$ ). Eucalyptus leaves had less shredders associated with them than alder leaves, an effect that was mainly caused by B. modesta on alder leaves (ANO$\mathrm{VA}, \mathrm{F}=12.77, \mathrm{p}=0.001$ ) and the high density of Orthocladiinae on eucalyptus leaves (table 3 ).

\section{DISCUSSION}

The choice of a method to study litter breakdown in ctreams should be based on the degree to which it mimics the conditions occurring naturally in streains, on reliability, simplicity, and required effort.

Litter enters streamc mainly as abscised leaves and accumulates as loose packs. Bags confine leaves and may thus create conditions that could affect invertebrate colonisation negatively. Tying leaves tightly to bricks might also limit invertebrate access. Both leaf species studied had higher breakdown rates when exposed as packc than when enclosed in bags. Leaf packs are exposed to the current and once conditioning has occurred, they may be readily frdgmented by physical action. Bagc protect the leaves from scouring and fragmentation; however, they also trap sediments, that may reduce the build-up of microorganisms and clow down breakdown (CHAUVET, 1987). Furthermore, bags can shield animals from the current (see BOULTON \& BOON, 1991), and the bag itself provides a structure that can be readily colonised by invertebrates. This idea is supported by the higher number of invertebrate taxa and densities in both alder and eucalyptus bags. Similarly, the preferente of shredderc for packs and that of collectors for bags indicate differences in resource availability between both treatments. The reprecentation of shredders and collectors was similar in bags and brick packs, whereas packs were dominated by shredders. This finding may indicate higher amounts of fine particulate organic matter in bags and brick packs. Leaves tied to bricks and mesh bags had similar breakdown rates, a result reported also by other studies (e.g., BENFIELD et al., 1979; MERRIT \& LAWSON, 1979; WEBSTER \& WAIDE, 1982; TATE \& GURTZ. 1988). while others have found differences (e.g., RAU, 1978; CUMMINS et al., 1980; MUTCH et al.. 1983: YATES \& DAY. 1983).

Litter retention in Galician streams is highest in summer, when water flow is low and litter input important. In the Mera stream, litter inputs from riparian trees (alder, birch) increace from summer to autumn (LÓPEZ, unpublished data). In

Table 3. Mean and standard error of richnesa. total density, relative and absolute density of shredders and collector-gatherers, and absolute density of Brillia modesta and Orthocladinae. ANOVA I (F,p) for treatment is provided when ANOVA II (treatment $\mathbf{x}$ time) was significant $(\mathbf{p}<0.05)$.

\begin{tabular}{|c|c|c|c|c|c|c|c|c|}
\hline COMPARISONS & $\begin{array}{l}\text { Richness } \\
\left(n^{\circ} \text { tax.) }\right.\end{array}$ & $\begin{array}{l}\text { Density } \\
\text { (ind } g-1 \text { ) }\end{array}$ & $\begin{array}{c}\text { Shredders } \\
(\%)\end{array}$ & $\begin{array}{c}\text { Col.-gatherers } \\
(\%)\end{array}$ & $\begin{array}{l}\text { Shredders } \\
\text { (ind } \mathrm{g}^{-1} \text { ) }\end{array}$ & $\begin{array}{l}\text { Col.-gatherers } \\
\text { (ind } \mathrm{g}^{-1} \text { ) }\end{array}$ & $\begin{array}{l}\text { B. modesta } \\
\text { (ind } \mathrm{g}^{-1} \text { ) }\end{array}$ & $\begin{array}{l}\text { Orthocladinae } \\
\text { (ind } \mathrm{g}^{-1} \text { ) }\end{array}$ \\
\hline \multicolumn{9}{|l|}{ 1- Exposure technique: } \\
\hline \multicolumn{6}{|l|}{ Alder: $(\mathbf{F}, \mathbf{p})$} & \multicolumn{3}{|c|}{$(2.29,0.111)$} \\
\hline AP (packs) & $6.82 \pm 0.70$ & $10.49 \pm 1.53$ & $52.69 \pm 4.17$ & $27.87 \pm 5.12$ & $5.17 \pm 0.76$ & 3.7610 .88 & $4.32 \pm 0.71$ & $1.39 \pm 0.43$ \\
\hline $\mathrm{AB}$ (bags) & $9.80 \pm 1.17$ & $13.36 \pm 2.26$ & $40.35 \pm 6.10$ & $34.96 \pm 4.92$ & 4.4320 .69 & $6.20 \pm 1.49$ & $2.28 \pm 0.39$ & $2.36 \mathrm{k} 0.58$ \\
\hline $\mathrm{ABr}$ (bricks) & $7.85 \pm 0.96$ & 10.64 I 1.90 & 40.0515 .51 & $35.09 \pm 5.85$ & $4.06 \pm 0.83$ & $3.51 \pm 0.75$ & $2.59 \pm 0.54$ & $1.65 \pm 0.39$ \\
\hline Eucalypt: (F, p) & $(4.69,0.037)$ & & & & & $(3.80,0.059)$ & & $(3.91,0.056)$ \\
\hline $\mathrm{EP}($ packc) & 3.72 I 0.78 & $6.60 \pm 1.68$ & 30.2016 .91 & $43.56 \pm 8.20$ & $2.08 \pm 0.67$ & $2.62 \mathrm{k} 0.96$ & $1.53 \pm 0.57$ & $1.76 \pm 0.78$ \\
\hline EB (bags) & $7.00 \mathbf{I} 1.13$ & $9.95 \pm 1.68$ & $31.27 \pm 6.09$ & $43.86 \pm 6.65$ & $2.30 \pm 0.49$ & $5.50 \pm 1.10$ & $0.77 \pm 0.16$ & 4.0110 .98 \\
\hline 2-Site: $(F, p)$ & & & $(4.78,0.036)$ & & & & & \\
\hline AP (alder, riffles) & $6.82 \pm 0.70$ & $10.49 \pm 1.53$ & 52.6914 .17 & $27.87 \pm 5.12$ & $5.17 \mathrm{a} 0.76$ & $3.76 \pm 0.88$ & $4.32 \pm 0.71$ & $1.39 \pm 0.43$ \\
\hline API (alder, pools) & $9.601 \quad 1.04$ & $13.99 \pm 2.13$ & $39.10 \pm 4.48$ & $36.26 \mathrm{k} 3.86$ & $4.97 \mathrm{k} 0.74$ & $6.171 \quad 1.24$ & $3.49 \pm 0.57$ & 1.5110 .43 \\
\hline 3- Leaf age: $(F, p)$ & & $(\mathbf{0 . 8 1}, 0.376)$ & & & $(0.38 .0 .541)$ & $(2.42,0.129)$ & & $(0.13,0.723)$ \\
\hline AG (alder green) & $7.53 \pm 0.92$ & $17.65 \pm 3.04$ & $40.37 \pm 4.40$ & $40.54 \pm 5.36$ & $7.66 \pm 1.38$ & $6.92 \pm 1.33$ & $6.67 \pm 1.37$ & $2.14 \pm 0.79$ \\
\hline AP (alder abscissed) & $6.82 \pm 0.70$ & $10.49 \pm 1.53$ & $52.69 \pm 4.17$ & $27.87 \pm 5.12$ & 5.17 I 0.77 & $3.76 \mathbf{I} 0.88$ & $4.32 \pm 0.71$ & $1.39 \pm 0.43$ \\
\hline \multicolumn{5}{|c|}{ 4- Leaf species: $(\mathbf{F}, \mathbf{p})(11.18,0.002)(6.73,0.014)$} & \multicolumn{4}{|c|}{$(7.86,0.008)(12.63 .0 .001)(12.77,0.001)$} \\
\hline EP (eucalypt) & $3.72 \pm 0.78$ & $6.60 \pm 1.68$ & $26.85 \pm 6.54$ & $38.72 \pm 7.99$ & $5.17 \pm 0.76$ & $2.62 \pm 0.96$ & $1.53 \pm 0.57$ & $1.76 \pm 0.78$ \\
\hline AG (alder) & $7.53 \pm 0.92$ & 17.6513 .04 & 40.3714 .40 & $40.54 \pm 5.36$ & $2.08 \pm 0.67$ & $6.92 \pm 1.33$ & $6.67 \pm 1.37$ & $2.14 \pm 0.79$ \\
\hline
\end{tabular}


autumn, discharge variations result in great differences in the amounts of litter depocited in pools and rifflec, as most litter is scoured from the riffles. This study was carried out in autumn. when we expected highest differences in invertebrate abundances between pools and riffles. We expected to find higher leaf processing rates in riffles than in pools, because of the importance of physical factors such as current. Other studies have reported faster processing in riffles (see WEBSTER \& BENFIELD, 1986). Nevertheless, decay rates were similar at both sites. Although average water velocity in riffles of the Mera stream wac about twice that found in pools, 0.33 and $0.12 \mathrm{~m} \mathrm{~s}^{-1}$, respectively, both can be considered similarly high, hence creating similar habitat conditions. This may have been the reason why the processing rates of leaves were similar in riffles and pools in autumn, when environmental conditions and food availability in both habitats was expected to differ niarkedly. Similar numbers of shredders and collectors colonised packs in pools, whereas packs in riffles chowed a consistent shredder dominance. The Mera stream represents the typical conditions of Galician headwater streams, where runs and riffles are the dominant habitats, and our results indicate that future studies of litter breakdown should be carried out in this habitat.

One of the problems in litter processirig studies is to obtain a homogeneous stock of leaves for constructing standardised experimental units. Should the solution be to use green leaves which can be eacily collected from trees at any moment? The decay rates determined in the present ctudy indicate that green alder leaves were processed slightly faster than abccised material. In agreement with our findings. other studies also reported faster processing of green material (CAMPBELL et al., 1992). Furthermore, the absolute and relative importance of shredders and collectors differed between the abscised and green material. Thus, future studies should be carricd out with naturally abscised leaves rather than with green leaves picked from treec.

Several studies (POZO. 1993; BASAGUREN \& POZO. 1994; CORTES et al., 1994) have reported different litter breakdown rates and colonisation patterns for alder and eucalyptus leaves, the commonest exotic species in forested headwater catchments of N Spain and N Portugal. Nevertheless, decay rates of alder and eucalyptus leaves were similar in the Mera stream. In agreement with CORTES et al. (1994) and POZO (1993), we found large differences in the colonisation of leaf packs by invertebrates: lower densities and numbers of taxa, and lower shredder densities on eucalyptus leaves, even though collectors and shredders were cimilarly well represented on both leaf types. Replacement of alder by eucalyptus in riparian corridors produces changes in the dynamics and composition of litter inputs to streams (POZO et al., 1997). Irrespective of leaf breakdown rates. invertebrate colonisation of eucalyptus differs substantially from that of alder in both quantitative and qualitative termc, what could have important consequences for nutrient cycling through benthic communities.

In accordance with the results obtained in this study, we suggest to use biological indicators to select the best rriethods to study leaf breakdown in ctreams. For instance, to study some of the moct important contributors in numbers to functional groups. These species, with their behaviour and feeding strategies, are representing habitat conditions, as well as resource type and availability. As an example, B. modesta (widespread in the studied stretch), feeds on leaf fragments and fungi, and prefers native abscised and green leaves tied as packs in riffles.

\section{ACKNOWLEDGEMENTS}

We are very grateful to Sam Lake and two anonymous referees for their review and useful comments on an early version of this paper. This work was supported by the researcli project XUGA29106A96, Xunta de Galicia.

\section{REFERENCES}

ABELHO, M. \& M.A.S. GRAÇA, 1996. Effects of eucalyptus afforestations on leaf litter dynamics and macroinvertebrate community structure of streams in central Portugal. Hydrobiologia, 324: 195-204.

BASAGUREN, A. \& J. POZO, 1994. Leaf litter processing of alder and eucalyptus in the Agüera strearn system (northern Spain). 11 Macroinvertebrates associated. Arch. Hydrobiol., 132: 57-68.

BENFJELD, E.F.. R.W. PAUL \& J.R. WEBSTER, 1979. Jnfluence of exposure technique on leaf breakdown ratec in streams. Oikos, 33: 386-391.

BLACKBURN, W.M. ¿?T. PETR, 1979. Forest litter decomposition and benthos in a mountain stream in Victoria, Australia. Arch. Hydrobiol., 86: 53-498.

BOULTON, A.J. \& P.I. BOON, 1991. A review of methodology uced to measure leaf litter decomposition in lotic environments: time to turn over an old leaf. Aust. J. Mar. Freshwat. Res, 42: 1-43.

CAMPBELL, I.C., K.R. JAMES, B.T. HART \& A. DEVEREAUX, 1992. Allochthonous coarse particulate organic material in forest and pasture reaches of two south-eastern Australian streams. IJ Litter processing. Freshwat. Biol., 27: 353-365.

CHAUVET, E., 1987. Changes in the chemical composition of alder, poplar and willow leaves during decomposition in a 
river. Hydrobiologia, 148: 35-44.

CORTES, R.M.V., M.A.S. GRAÇA \& A. MONZÓN, 1994. Replacement of alder by eucalyptus along two streams with different characteristics: Differences on decay rates and consequences to the system functioning. Verh. Int. Ver.Limnol., 25: 1697-1702.

CUMMINS, K.W., G.L. SPENGLER, G.M. WARD, R.M. SPEAKER, R.W. OVINK, D.C. MAHAN \& R.L. MATTINGLY, 1980. Processing of confined and naturally entrained leaf litter in a woodland stream ecosystem. Limnol. Oceanogr., 25: 952-957.

IMBERT, J.B. \& J. POZO, 1989. Breakdown of four leaf litter species and associated fauna in a Basque Country forested stream. Hydrobiologia, 182: 1-14.

MERRIT, R.W. \& D.L. LAWSON, 1979. Leaf litter processing in floodplain and stream communities. In: Strategies for protection and management of floodplain wetlands and other riparian ecosystems (R.R. JOHNSON \& J.F. McCORMICK, eds.): 93- 105. USDA. Washington.

MUTCH, R.A., R.J. STEEDMAN, S.B. BERTÉ \& G. PRITCHARD, 1983. Leaf breakdown in a mountain stream, a comparison of methods. Arch. Hydrobiol., 97: 89-108.

POZO, J., 1993. Leaf litter processing of alder and eucalyptus in the Agüera stream system (north Spain). I. Chemical changes. Arch. Hydrobiol., 127:299-317.

POZO J., E. GONZÁLEZ, J.R. DÍEZ, J. MOLINERO \& A. ELÓSEGUI, 1997. Inputs of particulate organic matter to streams with different riparian vegetation. J. N. Am. Benthol. Soc., 16: 602-611.
RAU, G.H., 1978. Conifer needle processing in a subalpine lake. Limnol. Oceanogr., 78: 153-160.

REICE, S.R., 1974. Environmental patchiness and the breakdown of leaf litter in a woodland stream. Ecology, 55: 12711282.

STRAHLER, A.N., 1964. Quantitative geomorphology of drainage basins and channel networks. In: Handbook of applied Hydrology. (V.T. CHOW, ed.): 4-39 to 4-76. McGraw-Hill. New York.

TATE, C.M. \& M.E. GURTZ, 1988. Comparison of mass loss, nutrients, and invertebrates associated with elm leaf litter decomposition in perennial and intermittent reaches of tallgrass prairie streams. Southwestern Nat., 31:511-520.

WEBSTER, J.R. \& J.B. WAIDE, 1982. Effects of clearcutting on leaf breakdown in a Southern Appalachian stream. Freshwat. Biol., 12: 331-334.

WEBSTER, J.R. \& E.F. BENFIELD, 1986. Vascular plant breakdown in freshwater ecosystems. Ann. Rev. Ecol. Syst., 17: 567-594.

YATES, R.F. \& F.P. DAY, Jr., 1983. Decay rates and nutrient dynamics in confined and unconfined leaf litter in the Great Dismal swamp. Am. Midl. Nat., 110: 37-45. 